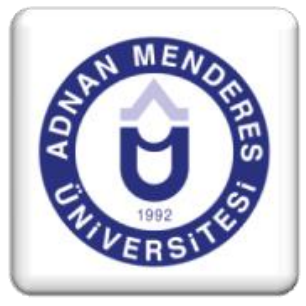

\title{
Muhasebe Meslek Mensuplarının Almış Oldukları Disiplin Cezalarının Kayıtlı Olunan Oda, Unvan ve Cinsiyet Açısından Değişimi: 2001-2015 Dönemi \\ Hasan GÜL ${ }^{1}$
}

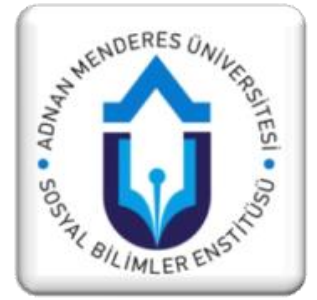

\section{ÖZET}

Muhasebe mesleği toplumsal sorumluluk ilkesi gereği kamu yararı gözetilerek icra edilmesi gereken son derece önemli bir meslek alanıdır. Dolayısıyla muhasebe meslek mensupları da mesleki faaliyetlerini yürütürken mesleki standartlara ve etik kodlara uyma mecburiyetini taşımaktadırlar. Muhasebe meslek mensuplarının mesleki standartlar ve etik ilkeler dışına çıkan uygulamaları disiplin cezalarına konu olmaktadır. Bu araştırmanın amacı muhasebe meslek mensuplarının aldığı disiplin cezalarının yıllar itibariyle gelișimini inceleyerek, bu cezaların kayıtlı olunan oda, unvan ve cinsiyet kategorilerine göre değişimini betimsel yöntemler kullanarak incelemektir. Bu kapsamda muhasebe meslek mensuplarının 2001-2015 dönemleri boyunca aldığ 1 ve TÜRMOB tarafindan yayınlanan Disiplin Kurulu kararları incelenerek büyüklüğü 1.514 olan bir veri seti elde edilmiştir. SPSS ve Microsoft Excel programları kullanılarak elde edilen bulguların sonuçlarına göre muhasebe meslek mensuplarının aldığı disiplin cezalarının yıllar itibariyle sayısal gelişimi ile muhasebe meslek mensuplarının yıllar itibariyle sayısal gelişimi paralellik göstermemektedir. Bununla birlikte muhasebe meslek mensuplarının aldığı disiplin cezaları ile bulundukları bölgede kayıtlı meslek mensuplarının sayısı, unvanlarına göre meslek mensuplarının sayısı ve cinsiyetlerine göre meslek mensuplarının sayısı oransal olarak farklılıklar göstermektedir.

Anahtar Kelimeler: Muhasebe Meslek Mensupları, Muhasebe Meslek Etiği, Disiplin Cezası, Disiplin Yönetmeliği

\section{The Changes on The Received Discipline Punishments by Professional Accountants Based on the Associations, Titles and Genders: Between The Years of 2001-2015}

\begin{abstract}
Accounting which must be professed based on social responsibility principle and public welfare is a quite significant area of profession. Also, professional accountants have to obey the occupational standards and ethics during performing their professional activities. Violation of professional standards and ethical principles means disciplinary regulations for professional accountants. The main purpose of this study is to investigate both the development of the received disciplinary punishments by professional accountants by years and the changes of these punishments based on the associations, titles and genders via utilizing descriptive methods. Therefore, in this study, the discipline committee regulations which is determined by professional accountants between the years of 2001-2015 years and is published by TÜRMOB is identified. Also, the data set is obtained with the magnitude as 1.514. In methodology part, the research results are analyzed via SPSS and Microsoft Excel tools. As a result, based on the findings, the quantitative development of the discipline punishments received by professional accountants by years has parallels with the quantitative development of professional accountants by years. Moreover, the discipline punishments received by professional accountants numerically differs from the number of professionals based on their associations, the number of professionals based on their titles and the number of professional based on their genders.
\end{abstract}

Keywords: Professional Accountants, Accounting Professional Ethics, Discipline Punishments, Disciplinary Regulations.

\footnotetext{
${ }^{1}$ Öğr.Gör.Dr., Çanakkale Onsekiz Mart Üniversitesi, Ezine Meslek Yüksekokulu, Muhasebe ve Vergi Bölümü.
} 


\section{Giriş}

Muhasebe mesleği son derece önemli bir faaliyet alanı olarak pek çok sorumluluk alanıyla çevrelenmiştir. Muhasebe meslek mensupları sadece müş̧eriler ve işverenlere karşı değil aynı zamanda toplumun tüm kesimlerine karşı -kamu yararı gözeterek- mesleki faaliyette bulunma sorumluluğu taşımaktadırlar. Çünkü muhasebe meslek mensuplarının mesleki ve etik standartlar dışına çıkan uygulamalarının önemli ekonomik ve toplumsal sonuçları olabilmektedir.

Muhasebe meslek mensupları bu sorumluluklarını ancak mesleki standartlara uymak ve mesleğin etik kodlarına bağlı kalarak yerine getirebilmektedirler. Muhasebe meslek mensuplarının standartlar ve etik ilkeler dışına çıkan uygulamaları kanun ve yönetmeliklerle yaptırıma tabi tutulmuştur. Bu kapsamda muhasebe meslek mensupları ve aday meslek mensupları için en önemli düzenlemelerden biri Serbest Muhasebeci Mali Müşavirlik ve Yeminli Mali Müşavirlik Kanunu Disiplin Yönetmeliği’dir.

Muhasebe meslek mensupları ve aday meslek mensuplarının disiplin soruşturması gerektiren eylem ve davranışları bu yönetmelik hükümleri doğrultusunda kayıtlı oldukları odalar eliyle yürütülmektedir. Muhasebe meslek mensuplarının kesinleşen disiplin cezaları resmi gazetede yayınlanmakta, ayrıca çeşitli kanallardan ilgililer ve kamuoyuyla paylaşılmaktadır.

$\mathrm{Bu}$ araştırmanın temel amacı muhasebe meslek mensuplarının aldığı disiplin cezalarının yıllar itibariyle gelişimini inceleyerek, bu cezaların kayıtlı olunan oda, unvan ve cinsiyet kategorilerine göre değişimini betimsel yöntemler kullanarak incelemektir. Gerek böylesi önemli bir mesleğin mensuplarının aldığı disiplin cezalarına ilişkin akademik manada çalışmaların yok denecek kadar az olması, gerekse bundan sonra bu konuya ilişkin yapılabilecek araştırmalar için bir temel ve referans olması bu araştırmanın nedenselliğini oluşturmaktadır.

$\mathrm{Bu}$ çalışma, giriş, literatür ve araştırma bölümleriyle birlikte sonuç kısımlarından oluşmaktadır. Giriş bölümünde araştırmanın nedenselliği ve araştırmanın bölümleri hakkında bilgi verilmeye çalışılmıştır. Literatür olarak isimlendirilen bölümde araştırmanın temel kavram ve değişkenleri hakkında yerli ve yabancı yazın kaynaklarından yararlanılarak bilgi verilmeye çalışılmıştır. Literatür bölümünde, muhasebe meslek mensupları ve muhasebe mesleğinin önemi, disiplin cezası kavramı ve muhasebe meslek mensupları disiplin yönetmeliği konuları ele alınmıştır. Çalışmanın araştırma bölümündeyse verilerin işlenmesiyle elde edilen bulgular tablo ve şekiller halinde sunulmuş ve elde edilen sonuçlar tartışılmaya çalışılmıştır. Araştırma bölümü, araştırmanın amacı ve önemi, araştırmanın yöntemi, araştırmanın sınırlılıkları ve araştırmanın bulguları kısımlarından oluşmaktadır. Sonuç ve öneriler bölümünde ise araştırma sonuçları özetlenerek bir takım önerilerde bulunulmaya çalışılmıştır.

\section{Muhasebe Mesleğinde Disiplin Cezaları ve Disiplin Yönetmeliği}

\subsection{Muhasebe Meslek Mensupları ve Muhasebe Mesleğinin Önemi}

Muhasebe meslek mensubu en basit ifadeyle muhasebecilik mesleğini profesyonel bir uğraş olarak yürüten kişilere denilmektedir. Muhasebe meslek mensubu formel eğitim ve uygulamada edindiği bilgilerini, becerilerini ve deneyimlerini talep edenlere, ilgili yasaların ve meslek kuruluşlarının çizdiği sınırlar içinde sunarak yaşamını sürdüren bir profesyoneldir (Y1ld1z, 2010: 158). 
Muhasebe meslek mensupları ${ }^{2}$ sistematik bir eğitim ve tecrübe ile kazandıkları bilgi ve becerilerini bir hizmet sözleşmesi ile bağlandıkları müşteri ya da işverenlerin hizmetine sunmaktadırlar (Gül, 2016: 7). Muhasebe mesleği açısından mesleki hizmet, muhasebe, denetim, vergi, yönetim danışmanlığı, finansal yönetim hizmetleri gibi muhasebe mesleği ile ilgili yetenek gerektiren hizmetleri ifade etmektedir (Etik İlkeler Yönetmeliği, Madde 4.j).

Muhasebe mesleği yarattığı dışsallık nedeniyle hata ve yanlış kabul eden bir faaliyet alanı değildir. Çünkü muhasebe mesleğinde yapılan hata ve yanlışların bütün toplum kesimlerini etkileme potansiyeli bulunmaktadır. Nitekim başta Enron, Worldcom, Parmalat ve Xerox gibi büyük muhasebe skandallarının son derece önemli etkileri olmuştur. Bu skandallar nedeniyle binlerce çalışan işlerini ve haklarını kaybederken yatırımcılar da milyarlarca dolar zarara uğramıştır. Ortaya çıkan krizler, işletme yöneticilerinin ve finansal analistlerin güvenilirliğini zedelemiştir. Ayrıca en büyük beş muhasebe firmasının yok oluşuna ve denetçilerin imajının lekelenmesine sebep olmuştur (Comunale et al., 2006: 638 aktaran Yardımcıŏglu ve Ada, 2013: 52). Bu nedenle meslek mensupları yürüttükleri faaliyetler sonucu sadece müşterilerine ya da işverenlerine karşı değil aynı zamanda toplumun tüm kesimlerine karşı da sorumluluk taşımaktadırlar (Ayboğa, 2001: 37; Güney ve Çınar, 2012: 96). Kamu yararına uygun hareket etme sorumluluğu muhasebe meslek mensuplarının belirleyici özelliklerinden birisidir $^{3}$ (Sakarya ve Kara, 2010: 62). Muhasebe mesleği bu bağlamda farklı ve özellikli bir uğraş türüdür.

Muhasebe meslek mensupları öncelikle hizmet sundukları işletme sahip ve yöneticilerine isabetli karar alabilmeleri için doğru ve güvenilir bilgi sağlama yükümlülüğü altındadırlar. Buna paralel olarak muhasebe meslek mensupları mesleki faaliyette bulunurken toplum ve devlete karşı da önemli oranda sorumluluk taşırlar. Dolayısıyla muhasebe meslek mensupları faaliyetlerini mesleki değerler ve etik kurallar çerçevesinde sürdürmek zorundadırlar (Seviğ, 2002: 2; Öğredik, 2006). Kesin, açıklanabilir ve şeffaf disiplin süreçleri ile desteklenmiş etik kurallar muhasebe mesleği gibi mesleklerin temel unsurlarındandır (Maurice, 1996 aktaran Canning ve O'Dwyer, 2001: 730).

\subsection{Disiplin Cezası}

Türk Dil Kurumu disiplini "kişilerin içinde yaşadıkları topluluğun genel düşünce ve davranışlarına uymalarını sağlamak amacıyla alınan önlemlerin bütünü” olarak tanımlamaktadır. Disiplin, yönetimin bireyin kurallara uygun davranışlara yönelebilmesini sağlayacak imkanları hazırlaması ve bu şartlar içinde bireyin davranışlarını kontrol atına

\footnotetext{
2 Türkiye'de 2008 tarihine kadar muhasebe meslek mensubu sıfatını "Serbest Muhasebeci'ler" (SM), "Serbest Muhasebeci Mali Müşavir'ler” (SMMM) ve "Yeminli Mali Müşavir'ler” (YMM) taşıyordu. 10.07.2008 tarihinde yayınlanan 5786 sayılı kanunla, Türkiye'de muhasebecilik mesleğini düzenleyen 3568 sayılı "Serbest Muhasebeci Mali Müşavirlik ve Yeminli Mali Müşavirlik Kanununda" değişikliğe gidilmiş ve yeni düzenlemede Serbest Muhasebeciler muhasebe meslek mensubu olarak sayılmamışlardır. Buna göre muhasebe meslek mensupları SMMM ve YMM'lerdir. Buna karşılık SM unvanına sahip olup devam ettirenler 3568 sayılı kanunun 45. Maddesinde belirtilen yasaklara ve meslek mensuplarına ilişkin düzenlemelere uymak zorunda tutulmuşlardır (Gül, 2016: 8). Bununla birlikte halen SM'ler muhasebe mesleğinin üst çatı kuruluşu olan Türkiye Serbest Muhasebeci Mali Müşavirler ve Yeminli Mali Müşavirler Odaları Birliği (TÜRMOB) tarafından yayınlanan meslek mensupları istatistiklerinde yer bulmaktadır. Dolayısıyla bu araştırma kapsamına SM'ler de dahil edilmiştir.

${ }^{3}$ Nitekim 3568 sayılı "Serbest Muhasebeci Mali Müşavirlik ve Yeminli Mali Müşavirlik Kanunu" muhasebe mesek mensuplarının bağlı bulundukları odaları ve birliği "kamu kurumu niteliğinde meslek kuruluşu" olarak saymış (Madde 14; Madde 28); ayrıca, muhasebe meslek mensuplarının "görevleri sırasında veya görevleri sebebiyle işledikleri suçlardan dolayı, fiillerinin niteliğine göre Türk Ceza Kanununun kamu görevlilerine ait hükümleri uyarınca" cezalandırılacağını (Madde 47) hükme bağlamıştır.
} 
alacak önlemleri almasıdır (Sorguç, 1980: 27). Bir başka tanımda disiplin, belirli bir hizmeti yürütmekle görevli meslek grubunun, beli bir öğenim ve eğitimden sonra önceden belirlenmiş, geçerli ve istenilen kurallara uymalarının sağlanmasıdır (Önder, 1985: 5).

Disiplin cezaları ise kamu ve özel hukuk kurumlarının ${ }^{4}$ iyi bir şekilde işleyebilmesi, bunların faaliyetlerinde bir disiplin ruhunu yaratabilmek ve bunun ihlali halinde de yaptırım uygulamak amacını taşımaktadır (Günal, 1958: 190). Disiplin cezası kamu yararı gözeten hizmetlerinin layık olduğu önem ve doğrulukta yerine getirilebilmesi için hizmet verenlerin üzerinde iyileştirme ve uyarı, bazen de tasfiye amacıyla konan belirli önlem ve kurallar bütünüdür. Disiplin cezası, kamu hizmeti niteliği taşıyan hizmetlerin, bu hizmeti vermesi gerekenlerce düzeni ve verimli bir biçimde yürütülebilmesini sağlamak, hizmette bulunanların unvan ve görevlerini olumsuz yönde etkileyebilecek davranışlarını önlemek amacıyla yönetim tarafindan konulmuş kurallara aykırı hareket edenlere uygulanan cezalardır (Sorguç, 1980: 29). Nerede organize bir topluluk varsa orada disiplinin korunmas1 için disiplin cezalarının varlığı da görülmektedir (Günal, 1958: 191).

Disiplin cezaları, (i) kamu hizmeti niteliğindeki hizmetlerin aksatılmadan ve sürekli bir şekilde yürütülebilmesi için kurumsal düzeyde uygulanan yaptırımların, (ii) kurum düzenini korumaya ve böylece devletin saygınlık ve güvenini sağlamaya yönelik tedbirlerin, (iii) hizmeti verenlerin mevzuat hükümlerine (kanun, tüzük ve yönetmelik vb.) göre uymak zorunda oldukları ödev ve sorumlulukları ihlal etmeleri halinde uygulanacak cezalara atıf yapan bir kavramdır (Uz, 2013: 6-7).

Disiplin cezaları mesleki standartlara ilişkin usulsüzlükleri tespit eden soruşturmalar sonucu ortaya çıkmaktadır (De Fuentes et al., 2015: 314). Disiplin cezalarının işlevi, yapılan göreve ya da verilen hizmete ilişkin standartlar dışına çıkan uygulamaları önlemek ve standartlar dışına çıkan eylemleri gerçekleştirenlere uygulanacak yaptırımlara bir standart getirmektir. Disiplin cezaları mesleki görevlerin ihlal edilmesi durumunda mesleki menfaatlerin korunması ve mesleki disiplinin sağlanması için alınan zorlayıcı tedbirlerdir. Disiplin cezaları uyarı ve kınama gibi manevi nitelikte olmakla birlikte, en ağır disiplin cezası meslekten çıkarılmadır ${ }^{5}$ (Günal, 1958: 192).

\subsection{Muhasebe Meslek Mensupları Disiplin Yönetmeliği}

Muhasebe meslek mensuplarına verilecek disiplin cezaları 31.10.2000 tarihinde 24216 sayılı Resmi Gazetede yayınlanarak yürürlüğe giren "Serbest Muhasebeci Mali Müşavirlik ve Yeminli Mali Müşavirlik Kanunu Disiplin Yönetmeliği ${ }^{\prime}$ " ile belirlenmiştir. Muhasebe meslek mensupları disiplin yönetmeliğinin amacı (Disiplin Yönetmeliği, Madde 1):

... meslek mensupları ve aday meslek mensupları hakkında, disiplin kovuşturması yapılmasına karar verecek yetkili organları, disiplin cezalarını vermeye yetkili organları, disiplin cezalarına karşı yapılacak itirazların usul ve esasları ve disiplinle ilgili diğer hususları düzenlemektir.

\footnotetext{
${ }^{4}$ Ortak menfaatlerini korumak için statülerinde disiplin cezası bulunmayan hemen hemen hiçbir topluluk bulunmamaktadır. Aile, eğitim öğretim kurumları ve özellikle kamu hizmeti veren kurum ve örgütlerin tamamında disiplin cezalarından söz edilebilir (Günal, 1958: 193-194).

5 Daha ağır sayılabilecek cezalar ceza hukukunun kapsamına girmekte ve adli cezalar olarak isimlendirilmektedirler. Adli cezalar genel olarak maddi karakterlidir. Adli cezalar, ölüm cezasına kadar derece derece ağırlaşabilmektedir (Günal, 1958: 192).

6 "Serbest Muhasebeci unvanıyla görev yapanlar ile Serbest Muhasebecilik stajına devam edenler, bu Yönetmelikte yer alan hükümlere tabidirler.” (Disiplin Yönetmeliği, Geçici Madde 2).
} 
Muhasebe meslek mensupları için disiplin yönetmeliğinde muhasebe meslek mensuplarına hangi hallerde disiplin cezası verileceği şu şekilde ifade edilmektedir (Disiplin Yönetmeliği, Madde 14):

Meslek onuruna veya mesleki standartlara aykırı eylem ve davranışlarda bulunanlarla, görevlerini yapmayan veya kusurlu olarak yapan veyahut görevinin gerektirdiği güveni sarsıcı hareketlerde bulunan meslek mensupları ve aday meslek mensupları hakkında; muhasebe ve müşavirlik hizmetlerinin gereği gibi yürütülmesi amacı ile durumun niteliğine ve ağıllık derecesine göre Kanunda yazılı disiplin cezaları uygulanır.

3568 Sayılı Serbest Muhasebeci Mali Müşavirlik ve Yeminli Mali Müşavirlik Kanunu'na göre meslek mensuplarına ve aday meslek mensuplarına uygulanacak disiplin cezaları şunlardır (Madde 48):

a) Uyarma: Meslek mensubuna ve aday meslek mensubuna, mesleğin yürütülmesinde daha dikkatli davranması gerektiğinin yazı ile bildirilmesidir.

b) Kınama: Meslek mensubuna ve aday meslek mensubuna, görevinde ve davranışlarında kusurlu olduğunun yazı ile bildirilmesidir.

c) Geçici olarak mesleki faaliyetten alıkoyma: Mesleki sıfatı saklı kalmak koşuluyla altı aydan az, bir yıldan fazla olmamak üzere, mesleki faaliyetten alıkoymadir.

d) Yeminli sıfatını kaldırma: Yeminli Mali Müşavirin yeminli sıfatının kaldırılması ve mührünün geri alınmasıdır.

e) Meslekten çıarma: Meslek mensubunun ruhsatnamesinin geri alınarak bir daha mesleği yürütmesine izin verilmemesidir.

Muhasebe meslek mensuplarının disiplin soruşturmaları kayıtlı oldukları oda eliyle yürütülür (Disiplin Yönetmeliği, Madde 19; Madde 22) . Oda disiplin kuruluna itirazlar Birlik Disiplin kuruluna yapılabilmektedir (Disiplin Yönetmeliği, Madde 28). Süresinde yapılmayan itirazlarda Oda Disiplin Kurulu kararları kesinleşir, süresinde yapılan itirazlarda ise Birlik Disiplin Kurulunun verdiği kararlar kesindir (Disiplin Yönetmeliği, Madde 29).

Disiplin cezaları kesinleşme tarihinden itibaren ilgili oda yönetim kurulu başkanlığınca uygulanır. Uyarma ve kınama cezaları hariç diğer disiplin cezaları; Maliye Bakanlığı ile diğer ilgili kurum ve kuruluşlara duyurulur. Geçici olarak mesleki faaliyetten alıkoyma, meslekten çıkarma ve yeminli sıfatının kaldırılması cezaları; Resmî Gazete'de ve meslek mensubunun bağlı olduğu Oda ve Birlik internet sayfasında yayımlanır ve yöresinde uygun araçlarla ilan olunur (Disiplin Yönetmeliği, Madde 12).

\section{Araştırma}

\subsection{Araştırmanın Amacı ve Önemi}

$\mathrm{Bu}$ araştırmanın temel amacı muhasebe meslek mensuplarının aldığı disiplin cezalarının yıllar itibariyle gelişimini inceleyerek, bu cezaların kayıtlı olunan oda, unvan ve cinsiyet kategorilerine göre değişimini betimsel yöntemler kullanarak incelemektir. Bu kapsamda 2001-2015 dönemleri boyunca muhasebe meslek mensuplarının aldığı disiplin cezaları inceleme konusu yapılmıştır. 
$\mathrm{Bu}$ araştırmanın önemi bir kaç noktada ortaya çıkmaktadır. Öncelikle literatür üzerinde yapılan araştırmada muhasebe meslek mensuplarının aldığı disiplin cezaları üzerine yapılan araştırmaların son derece kısıtlı olduğu gözlenmiştir. Banar ve Aslan (2009: 93) da konuya ilişkin yaptıkları bir araştırmada muhasebe mesleğinde disiplin cezaları ve bunlarla ilgili uygulamalar üzerinde çok durulmadığını belirtmişlerdir. Bu çalışmanın bir başka önemi de muhasebe meslek mensuplarının aldığı disiplin cezalarının betimsel düzeyde araştıran bu çalışmanın konuya ilişkin bundan sonraki araştırmalar için de bir temel ve referans noktası oluşturabilecek olmasıdır. Bunlara ek olarak muhasebe mesleği kamu hizmeti niteliğinde bir faaliyet alanı olduğundan meslek mensuplarının aldığı disiplin cezaları tüm toplumu ilgilendirmektedir. Dolayısıyla bu konuda yapılacak araştırmaların hem topluma hem de mesleğin gelişimine katkı yapacağı söylenebilir.

\subsection{Araștırmanın Yöntemi}

$\mathrm{Bu}$ çalışma betimleyici araştırma yöntemleri kullanılarak yapılandırılmıştır. Betimleme, neyin ne olduğunun, şeylerin nasıl başlayıp sürdüğünün veya bir durumun, kişinin ya da olayın neye benzediğini resmetmektir. Betimleme, karmaşık şeyleri kavranabilir duruma getirmekle ilgilidir (Punch, 2005: 16). Betimleyici istatistiki yöntemler ise elde edilen verilerin organize edilmesi, özetlenmesi, adlandırılması, verilerin tümünü temsil edecek değerlerin bulunmasını içeren metotların tümüne denmektedir (Ural ve Kılıç, 2013: 78).

Bu kapsamda TÜRMOB resmi sitesinde yayınlanan ve 2001-2015 dönemini kapsayan Disiplin Kurulu kararları incelenerek büyüklüğ̈̈ 1.514 olan bir veri seti elde edilmiştir. TÜRMOB'un yayınladığı verilerden, Disiplin Kurulu kararının tarihi, disiplin cezası alan muhasebe meslek mensubunun kayıtlı olduğu oda, unvanı, ismi ve verilen disiplin cezasının türü bilgilerine ulaşmak mümkün olmaktadır. Elde edilen verilerin işlenmesinde SPSS 13.0 ve Microsoft Office Excel 2010 programları kullanılmıştır.

\subsection{Araştırmanın Sinırlılıkları}

$\mathrm{Bu}$ araştırmada muhasebe meslek mensuplarının (YMM, SMMM, SM) aldığı disiplin cezaları konu edilmiş, aday meslek mensuplarının aldığı disiplin cezaları kapsam dışı tutulmuştur. Araştırma, 2000 yılı Kasım ayı (2000 yılı içinde bulunan iki aylık sürede alınan disiplin cezaları 2001 yılı içinde sayılmıştır) ile 2015 y1llı aralık ayı sonuna kadar olan dönemi kapsamaktadır. Bunun temel sebebi muhasebe meslek mensuplarına uygulanacak disiplin cezalarına ilişkin hükümlerin yayınlandığ 1 "Serbest Muhasebeci Mali Müşavirlik ve Yeminli Mali Müşavirlik Kanunu Disiplin Yönetmeliği’nin" 31.10.2010 tarihinde yayınlanarak yürürlüğe girmesidir. Ayrıca, disiplin cezalarının tarihlenmesinde Disiplin kurulu kararlarının uygulandığı yıl değil ilan edildiği yıl baz alınmıştır. Araştırmada disiplin cezaları olarak "geçici olarak mesleki faaliyetten alıkoyma" ve "meslekten çıkarma" cezaları konu edilmiştir. Bunun sebebi ise sadece "geçici olarak mesleki faaliyetten alıkoyma", "meslekten çıkarma" ve "yeminli sıfatının kaldırılması" cezalarının kamuoyuyla paylaşılmasıdır. Yönetmeliğe göre "uyarma" ve "kınama" cezaları kamuoyuyla paylaşılmamaktadır. Ayrıca "yeminli sıfatının kaldırılması" cezası da 2001-2015 dönemi boyunca muhasebe meslek mensuplarınca çok az sayıda alındığ 1 için bu araştırmada kapsam dışı bırakılmıştır.

\subsection{Araştırmanın Bulguları}

\subsubsection{Muhasebe Meslek Mensuplarının Almış Oldukları Disiplin Cezalarının Yıllar İtibarıyla Değişimi}

Muhasebe meslek mensuplarının almış oldukları disiplin cezaları 2001-2015 dönemi boyunca incelendiğinde toplam 1.514 cezanın verilmiş olduğu görülmektedir. Muhasebe 
meslek mensuplarının 2001-2015 dönemi boyunca aldıkları disiplin cezalarının dağılımı Tablo 1'de gösterilmiştir.

Tablo 1. Muhasebe Meslek Mensuplarının Almış Oldukları Disiplin Cezalarının Yıllar İtibarıyla Dağılımı (2001-2015)

\begin{tabular}{|c|c|c|c|}
\hline Yillar & $\begin{array}{l}\text { Geçici Olarak Mesleki } \\
\text { Faaliyetten Alıkoyma }\end{array}$ & Meslekten Çıkarma & Toplam \\
\hline 2001 & 78 & 16 & 94 \\
\hline 2002 & 59 & 20 & 79 \\
\hline 2003 & 96 & 47 & 143 \\
\hline 2004 & 65 & 63 & 128 \\
\hline 2005 & 54 & 31 & 85 \\
\hline 2006 & 76 & 26 & 102 \\
\hline 2007 & 72 & 51 & 123 \\
\hline 2008 & 72 & 25 & 97 \\
\hline 2009 & 43 & 24 & 67 \\
\hline 2010 & 84 & 45 & 129 \\
\hline 2011 & 68 & 25 & 93 \\
\hline 2012 & 61 & 14 & 75 \\
\hline 2013 & 72 & 20 & 92 \\
\hline 2014 & 67 & 33 & 100 \\
\hline 2015 & 87 & 20 & 107 \\
\hline Toplam & 1054 & 460 & 1514 \\
\hline
\end{tabular}

Tablo 1'e göre muhasebe meslek mensuplarının 2001-2015 dönemi boyunca aldıkları toplam 1.514 disiplin cezasının 1.054 adedi "geçici olarak mesleki faaliyetten alıkoyma" cezası, 460 adedi ise "meslekten çıkarma" cezası şeklinde verilmiştir. Meslek mensuplarının toplamda en çok disiplin cezası aldığı yıl 143 cezayla 2003 yılıdır. 2003 yılında 96 meslek mensubu geçici olarak mesleki faaliyetten alıkoyma cezası alırken, 47 meslek mensubu meslekten çıkarma cezası almıştır. Meslek mensuplarının en az disiplin cezası aldığı yıl toplam 67 disiplin cezasıyla 2009 yılı olmuştur. 2009 yılında 43 meslek mensubu geçici olarak mesleki faaliyetten alıkoyma cezası alırken, 24 meslek mensubu meslekten çıkarma cezası almıştır.

2001-2015 döneminde meslek mensuplarının almış oldukları disiplin cezalarının ortalaması yaklaşık 101'dir. Geçici olarak mesleki faaliyetten alıkoyma cezasının yıllık ortalaması yaklaşık 70 iken, meslekten çıkarma cezasının ortalaması yaklaşık 31 'dir. 
Tablo 2. Geçici Olarak Mesleki Faaliyetten Alıkoyma Cezalarının Yıllar İtibarıyla Dağılımı (2001-2015)

\begin{tabular}{|c|c|c|c|c|c|c|c|c|}
\hline Yillar & 6 Ay & 7 Ay & 8 Ay & 9 Ay & $10 \mathrm{Ay}$ & $11 \mathrm{Ay}$ & 12 Ay & Toplam \\
\hline 2001 & 46 & & 1 & & & 1 & 30 & 78 \\
\hline 2002 & 28 & 1 & 1 & 1 & & & 28 & 59 \\
\hline 2003 & 49 & & 1 & 1 & & & 45 & 96 \\
\hline 2004 & 24 & & & 2 & & & 39 & 65 \\
\hline 2005 & 21 & & & 1 & & & 32 & 54 \\
\hline 2006 & 34 & & & 1 & & & 41 & 76 \\
\hline 2007 & 44 & & & 1 & & & 27 & 72 \\
\hline 2008 & 40 & 1 & & 2 & & & 29 & 72 \\
\hline 2009 & 20 & & 1 & & & & 22 & 43 \\
\hline 2010 & 43 & & & 2 & 1 & & 38 & 84 \\
\hline 2011 & 40 & & & 1 & & & 27 & 68 \\
\hline 2012 & 31 & 1 & 1 & 1 & & & 27 & 61 \\
\hline 2013 & 40 & & & & & & 32 & 72 \\
\hline 2014 & 30 & & & 1 & & & 36 & 67 \\
\hline 2015 & 38 & & & 1 & & & 48 & 87 \\
\hline Toplam & 528 & 3 & 5 & 15 & 1 & 1 & 501 & 1054 \\
\hline
\end{tabular}

Geçici olarak mesleki faaliyetten alıkoyma cezaları kendi içinde ayrı olarak incelendiğinde meslek mensuplarının sayısal olarak en fazla " 6 ay mesleki faaliyetten alıkoyma" cezas 1 aldıkları görülmektedir. 2001-2015 dönemi boyunca meslek mensuplarının aldıkları 6 ay mesleki faaliyetten alıkoyma cezalarının toplam sayısı 528'dir. Bunu toplam 501 cezayla " 12 ay mesleki faaliyetten alıkoyma" cezası izlemektedir. 2001-2015 dönemi boyunca "10 ay mesleki faaliyetten alıkoyma" ve "11 ay mesleki faaliyetten alıkoyma" cezaları sadece birer defa verilmiştir. 


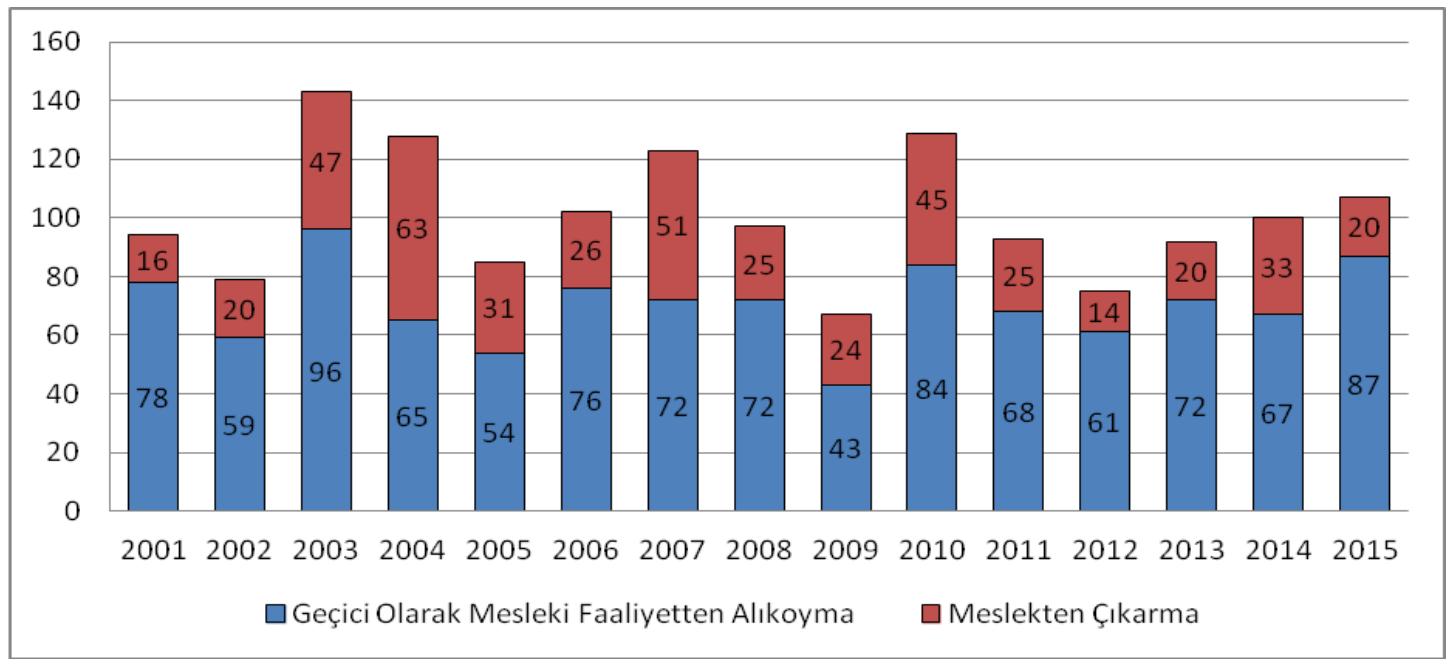

Şekil 1. Muhasebe Meslek Mensuplarının Almış Oldukları Disiplin Cezalarının Yıllara Göre Değişimi

Kaynak: TÜRMOB Disiplin Kurulu Kararlarından düzenlenmiştir http://www.turmob.org.tr/TurmobWeb/MBS/DisiplinKuruluKararlari.aspx (10.04.2016).

Şekil 1'de de görüldüğü üzere 2001-2015 dönemi içerisinde muhasebe meslek mensuplarının almış oldukları disiplin cezaları inişli çıkışlı bir seyir izlemektedir.

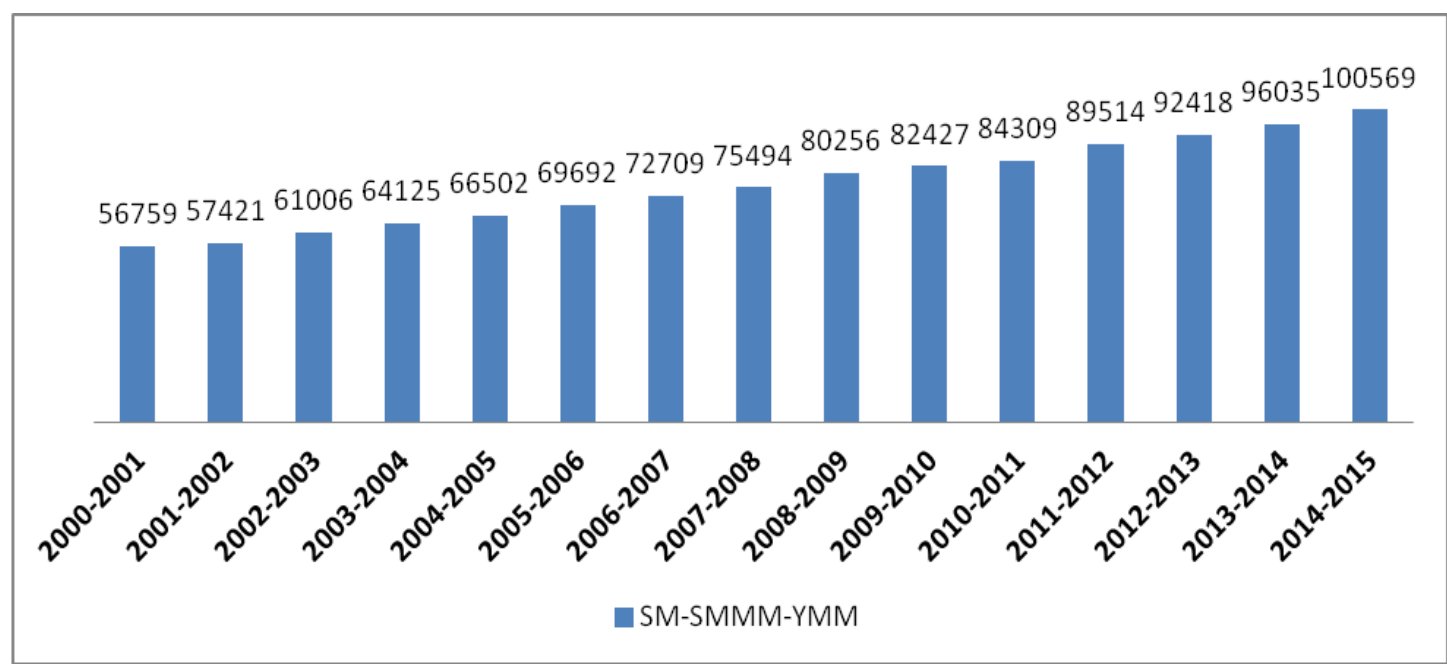

\section{Şekil 2. Yıllar İtibariyle Muhasebe Meslek Mensuplarının Sayıları}

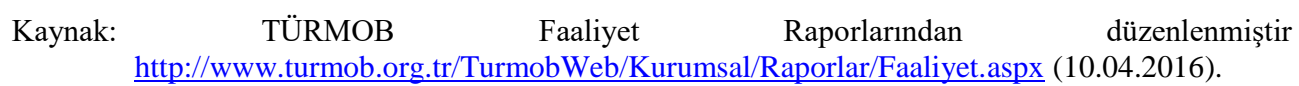

Şekil 2'ye göre 2000-2001dönemi sonunda 56.759 olan muhasebe meslek mensuplarının (YMM, SMMM ve SM toplamı) sayısı sürekli şekilde artarak 2014-2015 dönemi sonunda 100.569 kişiye ulaşmıştır.

Şekil 1 ve Şekil 2'deki veriler karşılaştırıldığında, yıllar itibariyle muhasebe meslek mensuplarının almış oldukları disiplin cezaları ile yıllar itibariyle muhasebe meslek mensuplarının sayıları arasında değişim yönünden bir benzerlik gözlenememektedir. Şekil 2 'de de görüleceği üzere muhasebe meslek mensuplarının sayısı yıllar itibariyle artış trendi göstermesine rağmen disiplin cezaları için bir artış ya da azalış trendinden bahsetmek 
mümkün görünmemektedir. Benzer şekilde, gerek geçici olarak mesleki faaliyetten alıkoyma cezası için, gerekse meslekten çıkarma cezası için de ayrıca bir artış ya da azalış trendinden bahsetmek mümkün görünmemektedir. Muhasebe meslek mensuplarının almış oldukları disiplin cezalarında zaman zaman yıllar itibariyle oransal olarak büyük sayılabilecek artış ya da azalışlar olmakla birlikte yatay bir seyir izlemektedir denilebilir.

\subsubsection{Muhasebe Meslek Mensuplarının Almış Oldukları Disiplin Cezalarının} Kayıtlı Oldukları Odaya Göre Değişimi

TÜRMOB'un kamuoyu ile paylaştığı disiplin kurulu karalarında disiplin cezası alan meslek mensuplarının kayıtlı olduğu oda bilgileri de bulunmaktadır. Şekil 3'de muhasebe meslek mensuplarının 2001-2015 dönemi boyunca aldıkları disiplin cezaları meslek mensuplarının kayıtlı oldukları odanın bulunduğu bölgeye göre sınıflandırılmıştır.

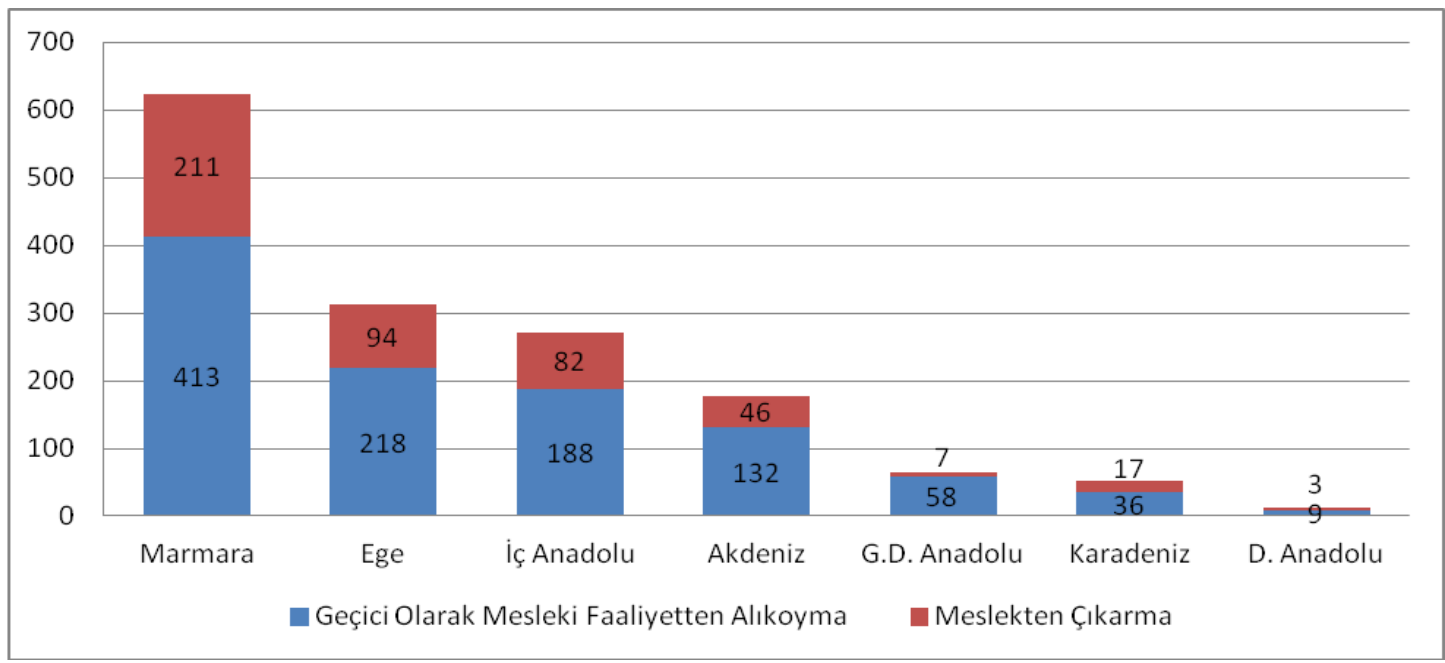

Şekil 3. Muhasebe Meslek Mensuplarının Aldığı Disiplin Cezalarının Kayıtlı Olunan Odanın Bulunduğu Bölgeye Göre Dağılımı (2001-2015)

$\begin{array}{ccccc}\text { Kaynak: } & \text { TÜRMOB } & \text { Disiplin } & \text { Kurulu } & \text { Kararlarından düzenlenmiştir } \\ \text { http://www.turmob.org.tr/TurmobWeb/MBS/DisiplinKuruluKararlari.aspx } & \text { (10.04.2016). }\end{array}$

Muhasebe meslek mensuplarının 2001-2015 dönemi boyunca aldıkları disiplin cezaları meslek mensuplarının kayıtlı oldukları odanın bulunduğu bölgeye göre incelendiğinde sayısal olarak en fazla cezayı Marmara Bölgesi içinde bulunan odalara kayıtlı meslek mensuplarının aldığı; en az cezayı ise Doğu Anadolu Bölgesi içinde bulunan odalara kayıtlı meslek mensuplarının aldığı görülmektedir. Şekil 3'e göre Marmara Bölgesi içinde bulunan odalara kayıtlı meslek mensupları toplam 624 disiplin cezası; Ege Bölgesi içinde bulunan odalara kayıtlı meslek mensupları toplam 312 disiplin cezası; İç Anadolu Bölgesi içinde bulunan odalara kayıtlı meslek mensupları toplam 270 disiplin cezası; Akdeniz Bölgesi içinde bulunan odalara kayıtlı meslek mensupları toplam 178 disiplin cezası; Güneydoğu Anadolu Bölgesi içinde bulunan odalara kayıtlı meslek mensupları toplam 65 disiplin cezası; Karadeniz Bölgesi içinde bulunan odalara kayıtlı meslek mensupları toplam 53 disiplin cezası; Doğu Anadolu Bölgesi içinde bulunan odalara kayıtlı meslek mensupları ise toplam 12 disiplin cezası almışlardır. 


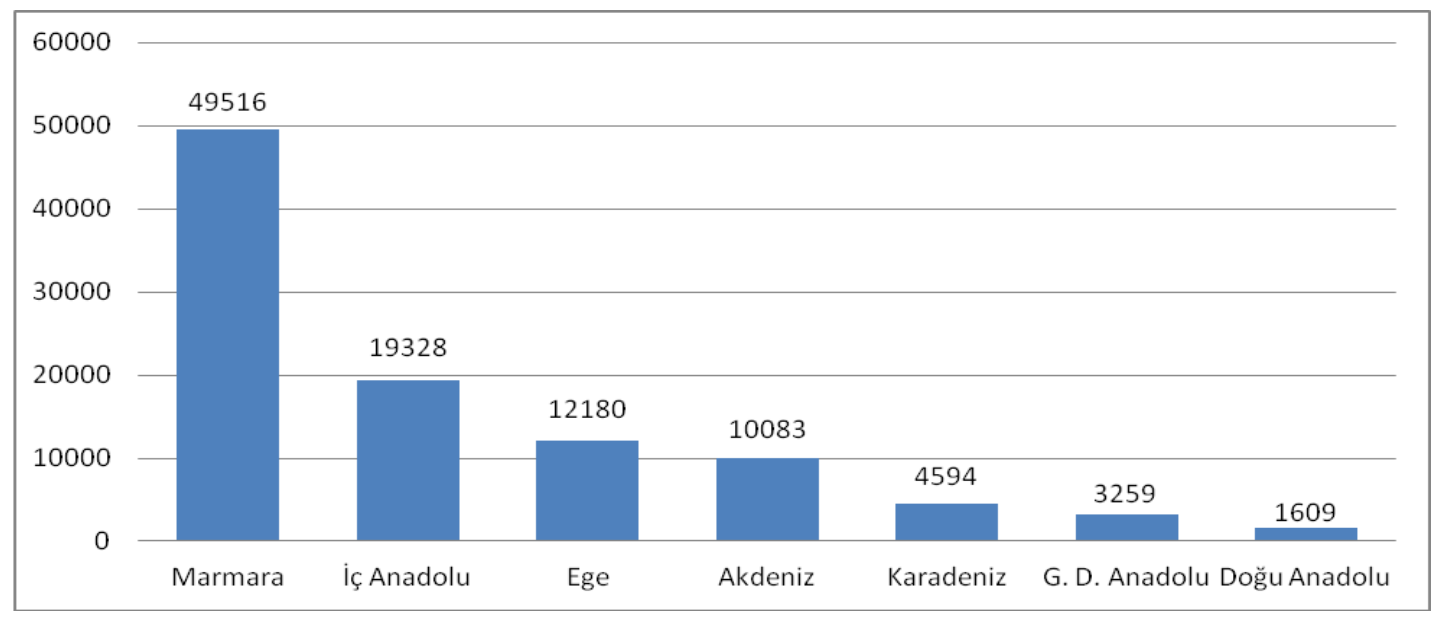

Şekil 4. Muhasebe Meslek Mensuplarının Kayıtlı Oldukları Odaların Bölgelere Göre Dağılımı

Kaynak:

TÜRMOB

Faaliyet

Raporlarından

düzenlenmiştir http://www.turmob.org.tr/TurmobWeb/Kurumsal/Raporlar/Faaliyet.aspx (10.04.2016).

Şekil 4'e göre 2015 yılı sonu itibariyle en çok muhasebe meslek mensubu 49.516 kişiyle Marmara bölgesinde, en az muhasebe meslek mensubu ise 1.609 kişiyle Doğu Anadolu bölgesinde bulunmaktadır.

Tablo 3. Muhasebe Meslek Mensuplarının Aldığı Disiplin Cezalarının Bölgelere Göre Sayısal ve Oransal Dağılımı

\begin{tabular}{|l|r|r|r|r|}
\hline & \multicolumn{2}{|c|}{ Meslek Mensupları } & \multicolumn{2}{c|}{ Disiplin Cezaları } \\
\cline { 2 - 5 } & Sayıs1 & Oran & Sayıs1 & Oran \\
\hline Marmara & 49.516 & 49,2 & 624 & 41,2 \\
\hline İç Anadolu & 19.328 & 19,2 & 270 & 17,8 \\
\hline Ege & 12.180 & 12,1 & 312 & 20,6 \\
\hline Akdeniz & 10.083 & 10,0 & 178 & 11,8 \\
\hline Karadeniz & 4.594 & 4,6 & 53 & 3,5 \\
\hline G.D. Anadolu & 3.259 & 3,2 & 65 & 4,3 \\
\hline D. Anadolu & 1.609 & 1,6 & 12 & 0,8 \\
\hline TOPLAM & 100.569 & 100,0 & 1.514 & 100,0 \\
\hline
\end{tabular}

Tablo 3'de muhasebe meslek mensuplarının aldıkları disiplin cezaları bulundukları bölgelerle karşılaştırılarak sunulmuştur. Tablo 3'e göre muhasebe meslek mensuplarının bölgelere göre dağılımı ile aldıkları disiplin cezaları oransal olarak paralellik göstermemektedir. Marmara bölgesinde bulunan odalara kayıtlı muhasebe meslek 
mensuplarının kayıtlı tüm muhasebe meslek mensuplarına oranı \% 49,2 iken, aldıkları disiplin cezalarının 2001-2015 dönemi boyunca alınan toplam disiplin cezalarına oranı \% 41,2'dir. Benzer şekilde İç Anadolu bölgesinde bulunan odalara kayıtlı meslek mensuplarının oranı \% 19,2 iken aldıkları disiplin cezalarının oranı \% 17,8; Ege bölgesinde bulunan odalara kayıtlı meslek mensuplarının oranı \% 12,1 iken aldıkları disiplin cezalarının oranı \% 20,6; Akdeniz bölgesinde bulunan odalara kayıtlı meslek mensuplarının oranı \% 10 iken aldıkları disiplin cezalarının oranı \% 11,8; Karadeniz bölgesinde bulunan odalara kayıtlı meslek mensuplarının oranı \% 4,6 iken aldıkları disiplin cezalarının oranı $\% 3,5$; Güneydoğu Anadolu bölgesinde bulunan odalara kayıtlı meslek mensuplarının oranı \% 3,2 iken aldıkları disiplin cezalarının oranı \% 4,3; Doğu Anadolu bölgesinde bulunan odalara kayıtlı meslek mensuplarının oranı \% 1,6 iken aldıkları disiplin cezalarının oranı \% 0,8'dir. Buna göre Marmara, İç Anadolu, Karadeniz ve Doğu Anadolu bölgesi içinde bulunan odalara kayıtlı muhasebe meslek mensupları oransal olarak daha az; Ege, Akdeniz ve Güneydoğu Anadolu bölgesinde bulunan odalara kayıtlı muhasebe meslek mensupları oransal olarak daha fazla disiplin cezası almışlardır denilebilir.

\subsubsection{Muhasebe Meslek Mensuplarının Almış Oldukları Disiplin Cezalarının Unvana Göre Değişimi}

TÜRMOB verilerinden yararlanılarak oluşturulan muhasebe meslek mensuplarının almış oldukları disiplin cezalarının unvana göre dağılımı Şekil 5'de sunulmuştur.

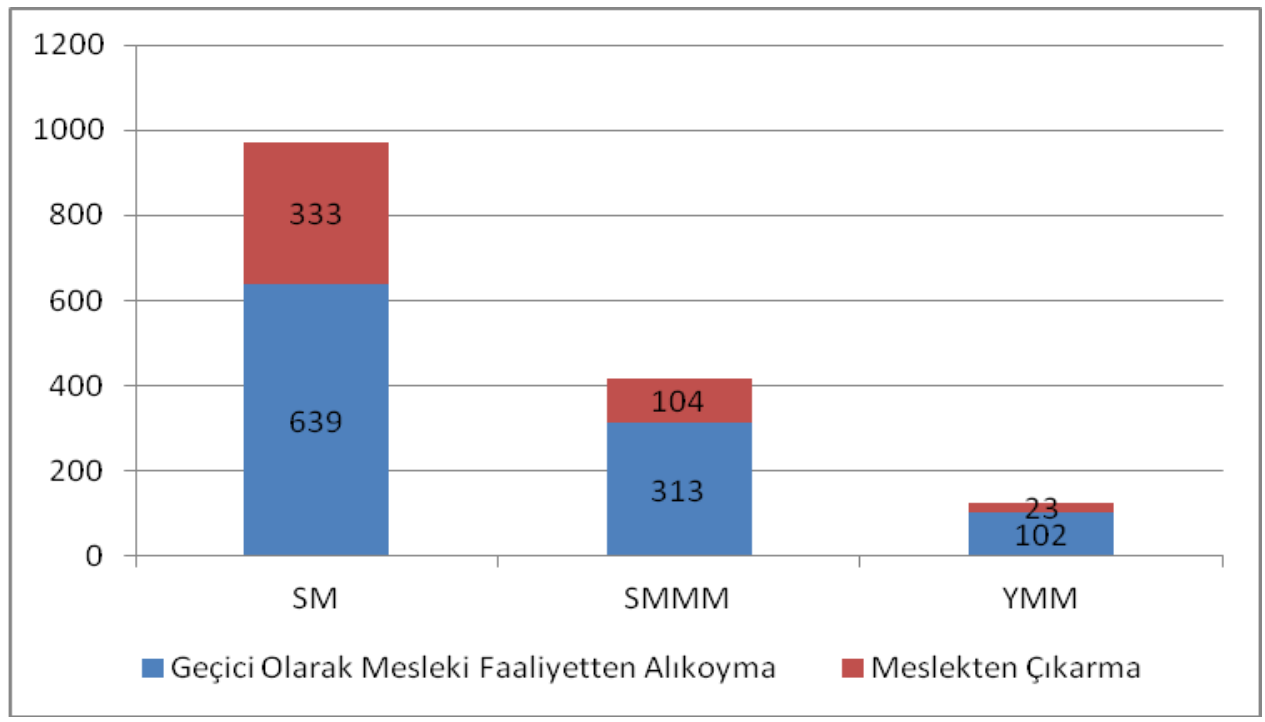

Şekil 5. Muhasebe Meslek Mensuplarının Almış Oldukları Disiplin Cezalarının Unvana Göre Dağılımı

(2001-2015)

$\begin{array}{ccccc}\text { Kaynak: } & \text { TÜRMOB } & \text { Disiplin } & \text { Kurulu } & \text { Kararlarından } \\ \text { http://www.turmob.org.tr/TurmobWeb/MBS/DisiplinKuruluKararlari.aspx } & \text { (10.04.2016). }\end{array}$

Muhasebe meslek mensuplarının 2001-2015 dönemi boyunca aldıkları disiplin cezaları meslek mensuplarının sahip oldukları unvana göre incelendiğinde sayısal olarak en fazla cezayı SM'lerin, en az cezayı ise YMM'lerin aldığı görülmektedir. Şekil 5'e göre SM unvanına sahip meslek mensupları toplam 972 disiplin cezası; SMMM unvanına sahip 
meslek mensupları toplam 417 disiplin cezas1; YMM unvanına sahip meslek mensupları ise toplam 125 disiplin cezası almışlardır.

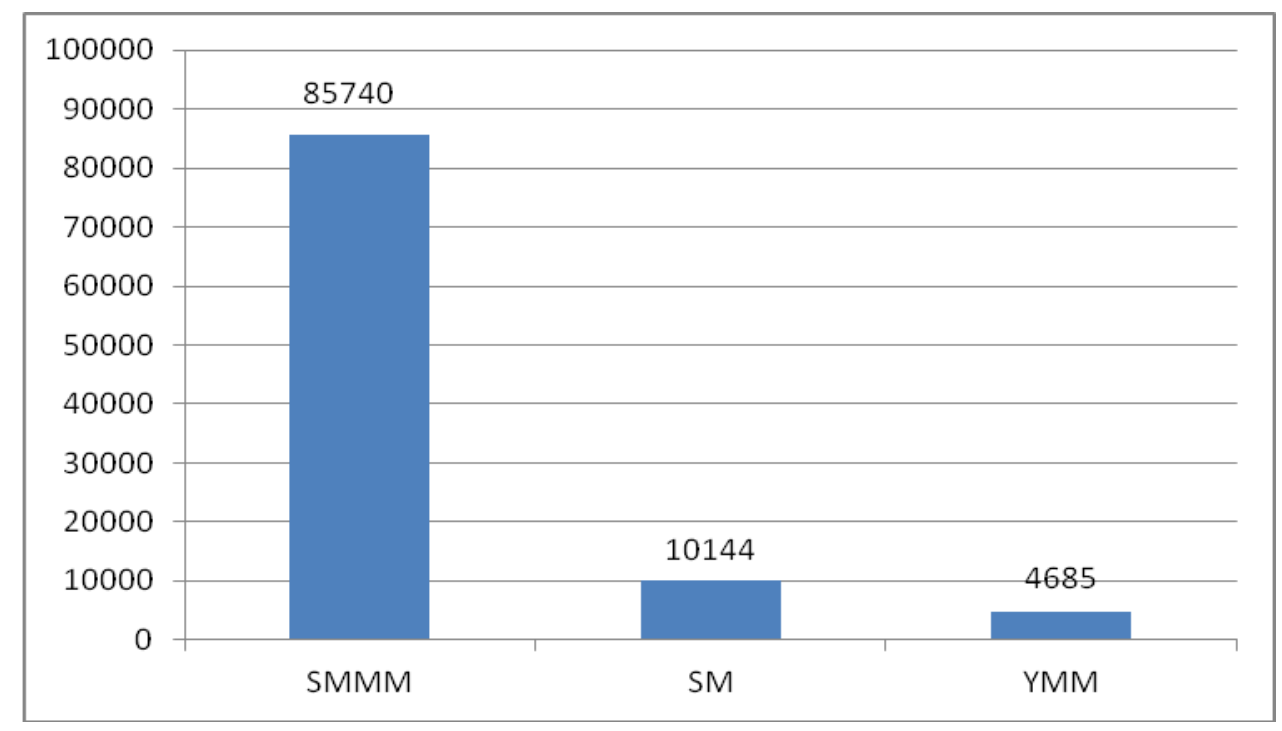

Şekil 6. Muhasebe Meslek Mensuplarının Unvana Göre Dağılımı

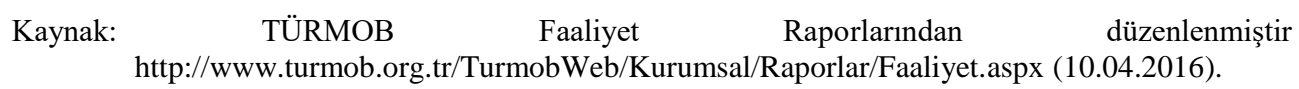

Şekil 6'da 2015 yılı sonu itibariyle Türkiye'deki muhasebe meslek mensuplarının unvana göre dağılımı sunulmuştur. 2105 yılı sonunda SMMM'lerin sayısı 85.740, SM'lerin sayısı 10.144, YMM'lerin sayısı ise 4.685 kişidir.

Tablo 4. Muhasebe Meslek Mensuplarının Aldığı Disiplin Cezalarının Unvana Göre Sayısal ve Oransal Dağılımı

\begin{tabular}{|l|r|r|r|r|}
\hline & \multicolumn{2}{|c|}{ Meslek Mensuplar1 } & \multicolumn{2}{c|}{ Disiplin Cezalar1 } \\
\cline { 2 - 5 } & Sayıs1 & Oran & Say1s1 & Oran \\
\hline SMMM & 85.740 & 85,3 & 417 & 27,5 \\
\hline SM & 10.144 & 10,1 & 972 & 64,2 \\
\hline YMM & 4.685 & 4,7 & 125 & 8,3 \\
\hline TOPLAM & 100.569 & 100,0 & 1.514 & 100,0 \\
\hline
\end{tabular}

Tablo 4'de muhasebe meslek mensuplarının sahip oldukları unvana göre ve aldıkları disiplin cezalarına göre dağılımı, hem sayısal hem de oransal olarak sunulmuştur. Tablo 4'e göre meslek mensuplarının unvanlarına göre dağılımı ile aldıkları disiplin cezaları oransal olarak paralellik göstermemektedir. SMMM unvanına sahip meslek mensuplarının kayıtlı tüm muhasebe meslek mensuplarına oran $1 \% 85,3$ iken, aldıkları disiplin cezalarının 2001-2015 dönemi boyunca alınan toplam disiplin cezalarına oranı \% 27,5; SM unvanına sahip meslek mensuplarının kayıtlı tüm muhasebe meslek mensuplarına oranı \% 10,1 iken aldıkları disiplin cezalarının 2001-2015 dönemi boyunca alınan toplam disiplin cezalarına oranı \% 
64,2; YMM unvanına sahip meslek mensuplarının kayıtlı tüm muhasebe meslek mensuplarına oranı \% 4,7 iken aldıkları disiplin cezalarının 2001-2015 dönemi boyunca alınan toplam disiplin cezalarına oran $1 \%$ 8,3'dür. Buna göre SMMM unvanına sahip olan meslek mensupları oransal olarak daha az, SM ve YMM unvanına sahip olan meslek mensupları ise oransal olarak daha çok disiplin cezası almışlardır denilebilir.

\subsubsection{Muhasebe Meslek Mensuplarının Almış Oldukları Disiplin Cezalarının} Cinsiyete Göre Değişimi

TÜRMOB verilerinden yararlanılarak oluşturulan muhasebe meslek mensuplarının almış oldukları disiplin cezalarının cinsiyete göre dağılımı grafiği Şekil 7'de sunulmuştur.

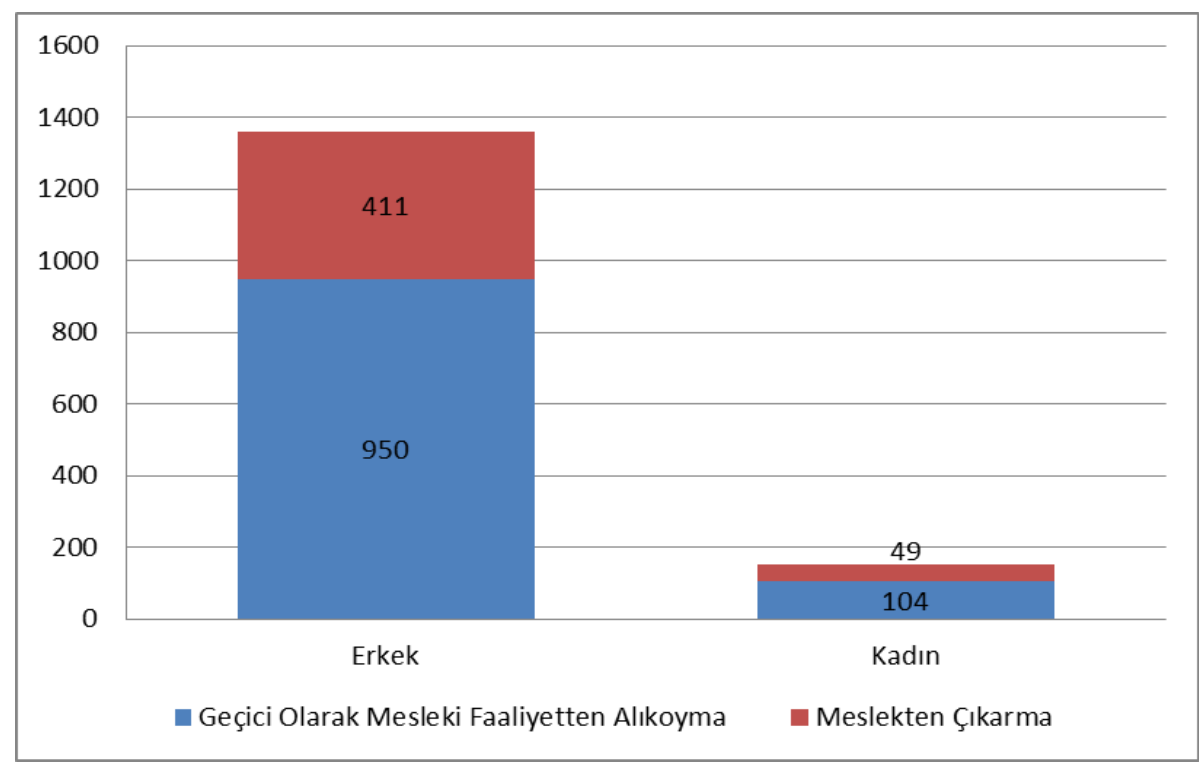

Şekil 7. Muhasebe Meslek Mensuplarının Almış Oldukları Disiplin Cezalarının Cinsiyete Göre Kaynak: Dağılımı (2001-2015)

$\begin{array}{cccc}\text { TÜRMOB } & \text { Disiplin } & \text { Kurulu } & \text { Kararlarından } \\ \text { düzenlenmiştir }\end{array}$

Muhasebe meslek mensuplarının 2001-2015 dönemi boyunca aldıkları disiplin cezaları meslek mensuplarının cinsiyetine göre incelendiğinde sayısal olarak en fazla cezayı erkek muhasebe meslek mensuplarının aldığı görülmektedir. Şekil 7'de de görüleceği üzere göre erkek muhasebe meslek mensupları toplam 1.361 disiplin cezası alırken; kadın muhasebe meslek mensupları toplam 153 disiplin cezası almışlardır. 


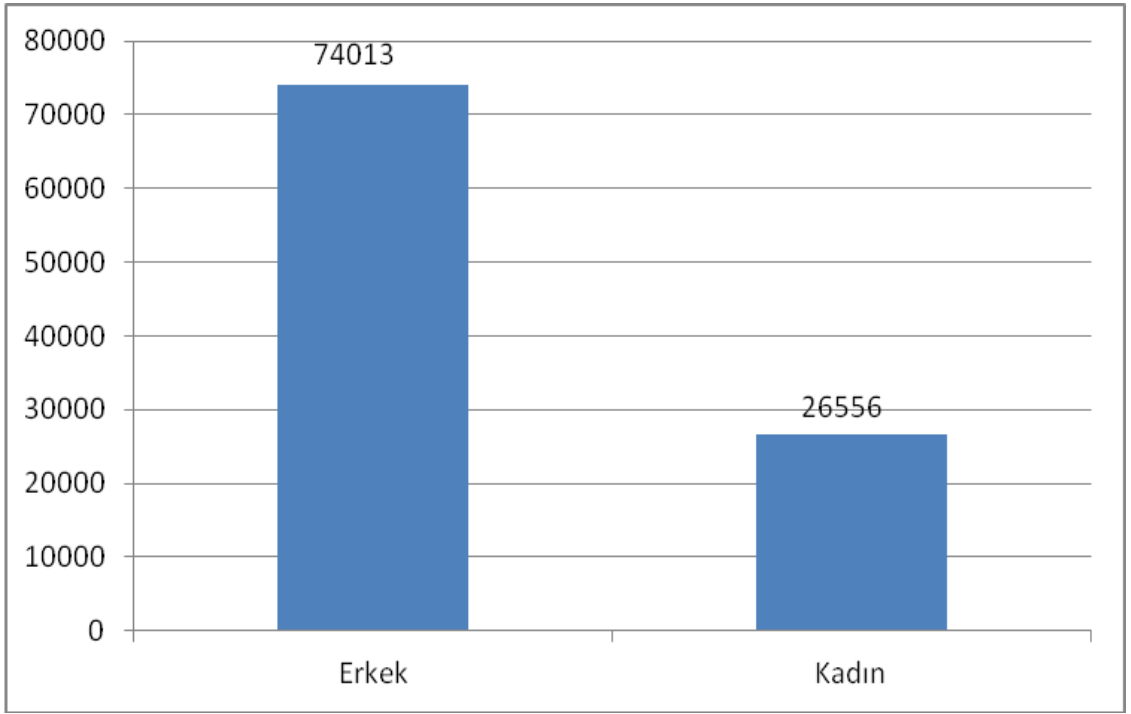

Şekil 8. Muhasebe Meslek Mensuplarının Cinsiyete Göre Dağılımı

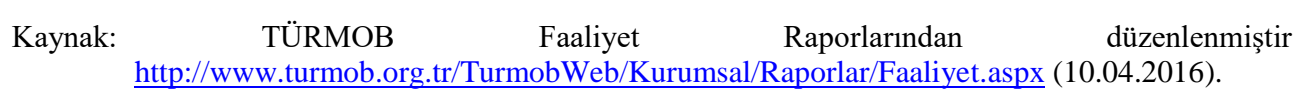

Şekil 8'de 2015 yılı sonu itibariyle Türkiye'deki muhasebe meslek mensuplarının cinsiyete göre dağılım grafiği sunulmuştur. 2015 yılı sonunda muhasebe meslek mensuplarının 74.013 tanesi erkek, 26.556 tanesi ise kadındır.

Tablo 5. Muhasebe Meslek Mensuplarının Aldığı Disiplin Cezalarının Cinsiyete Göre Sayısal ve Oransal Dağılımı

\begin{tabular}{|l|r|r|r|r|}
\hline \multirow{2}{*}{} & \multicolumn{2}{|c|}{ Meslek Mensuplar1 } & \multicolumn{2}{c|}{ Disiplin Cezalar1 } \\
\cline { 2 - 5 } & Sayı1 & Oran & Sayı1 & Oran \\
\hline Erkek & 74.013 & 73,6 & 1.361 & 89,9 \\
\hline Kadın & 26.556 & 26,4 & 153 & 10,1 \\
\hline TOPLAM & 100.569 & 100,0 & 1.514 & 100,0 \\
\hline
\end{tabular}

Tablo 5'de, muhasebe meslek mensuplarının cinsiyetine göre ve aldıkları disiplin cezalarına göre dağılımı hem sayısal hem de oransal olarak sunulmuştur. Tablo 5'e göre muhasebe meslek mensuplarının cinsiyete göre dağılımı ile aldıkları disiplin cezaları oransal olarak paralellik göstermemektedir. Erkek muhasebe meslek mensuplarının kayıtlı tüm muhasebe meslek mensuplarına oranı \% 73,6 iken aldıkları disiplin cezalarının 2001-2015 dönemi boyunca alınan toplam disiplin cezalarına oranı \% 89,9; kadın muhasebe meslek mensuplarının kayıtlı tüm muhasebe meslek mensuplarına oranı \% 26,4 iken aldıkları disiplin cezalarının 2001-2015 dönemi boyunca alınan toplam disiplin cezalarına oranı \% 10,1'dir. Buna göre erkek muhasebe meslek mensupları oransal olarak daha çok, kadın muhasebe meslek mensupları ise oransal olarak daha az disiplin cezası almışlardır denilebilir. 


\section{Sonuç ve Öneriler}

Muhasebe mesleği son derece önemli bir meslek alanı olarak tüm toplumsal kesimleri etkileme potansiyeli barındıran bir meslek alanıdır. Dolayısıyla bu mesleğin icracıları durumunda olan muhasebe meslek mensuplarının mesleki standartlar ve etik ilkeler dışına çıkan uygulamalarının tüm toplumu ilgilendiren bir yönü bulunmaktadır.

Bu çalışmada Türkiye'deki muhasebe meslek mensuplarının 2001-2015 dönemi boyunca aldıkları disiplin cezaları araştırma konusu yapılmış; bu amaçla, aldıkları disiplin cezalarının kayıtlı oldukları oda, unvan ve cinsiyet açısından değişimleri incelenmeye çalışılmıştır.

TÜRMOB tarafindan yayınlanan Disiplin Kurulu kararlarının işlenmesiyle elde edilen bulgulardan çıkan sonuçları şu şekilde özetlemek mümkündür:

(i) Muhasebe meslek mensuplarının aldığı disiplin cezalarının yıllar itibariyle sayısal gelişimi ile meslek mensuplarının yıllar itibariyle sayısı aynı biçimde değişim göstermemektedir. Muhasebe meslek mensuplarının sayısı her geçen yıl artış gösterirken, muhasebe meslek mensuplarının aldığı disiplin cezası sayısı inişli çıkışlı bir seyir izleyerek yatay sayılabilecek bir görünüm sergilemektedir.

(ii) Muhasebe meslek mensuplarının aldığı disiplin cezaları bölgelere göre sınıflandırılarak incelendiğinde, bölgelere kayıtlı meslek mensupları ile o bölgede bulunan odalara kayıtlı meslek mensuplarının aldığı cezalar oransal olarak paralellik göstermemektedir. Marmara, İç Anadolu, Karadeniz ve Doğu Anadolu bölgesi içinde bulunan odalara kayıtlı muhasebe meslek mensupları oransal olarak daha az; Ege, Akdeniz ve Güneydoğu Anadolu bölgesi içinde bulunan odalar kayıtlı muhasebe meslek mensuplarının ise oransal olarak daha çok disiplin cezası aldığı görülmektedir.

(iii) Muhasebe meslek mensuplarının aldığı disiplin cezaları meslek mensuplarının sahip olduğu unvana göre incelendiğinde, serbest muhasebeci mali müşavir (SMMM) unvanına sahip meslek mensuplarının oransal olarak daha az; serbest muhasebeci (SM) ve yeminli mali müşavir (YMM) unvanına sahip meslek mensuplarının oransal olarak daha çok disiplin cezası aldığı görülmektedir.

(iv) Muhasebe meslek mensuplarının aldığı disiplin cezaları meslek mensuplarının cinsiyetine göre incelendiğinde, erkek muhasebe meslek mensuplarının oransal olarak kadın muhasebe meslek mensuplarından daha çok disiplin cezası aldığı görülmektedir.

Muhasebe meslek mensuplarının aldığı disiplin cezaları üzerinde akademik manada araştırmalar yapmaya muhtaç bir konudur. Özellikle muhasebe meslek mensuplarının aldığı disiplin cezalarının kayıtlı olunan oda, unvan ve cinsiyet açısında farklılıklar göstermesi, bu farklılıklara sebep olan unsurların araştırılmasını ve karşılaştırmalı çalışmalar yapılmasının gerekliliğini ortaya sermektedir. 


\section{KAYNAKÇA}

BANAR, Kerim ve Ümmühan ASLAN. "Muhasebe Meslek Mensuplarının Almış Oldukları Disiplin Cezaları Üzerine Bir Araştırma (2000-2008 Dönemi)", Muhasebe ve Finansman Dergisi, Say1: 44, 2009, ss. 91-110.

CANNING, Mary ve Brendan O’DWYER. "Professional Accounting Bodies' Disciplinary Procedures: Accountable, Transparent and in the Public Interest?", The European Accounting Review, 10(4), 2001, ss. 725-749.

COMUNALE, Christie L.; Thomas R. SEXTON ve Stephen C. GARA. "Professional Ethical Crises: A Case Study of Accounting Majors", Managerial Auditing Journal, 21(6), 2006, ss. 636-656.

DE FUENTES, Cristina; Manuel ILLUECA ve Maria C. PUCHETA-MARTINEZ. "External Investigations and Disciplinary Sanctions Against Auditors: The Impact on Audit Quality", SERIEs, 2015, 6 (3), ss.313-347.

GÜL, Hasan. Muhasebe Meslek Mensuplarında İşe Bağlılık, Çalışma Ahlakı ve Mesleki Etik Davranış İlişkilerinin Değerlendirilmesi, (Yayınlanmamış Doktora Tezi), 2016, Çanakkale Onsekiz Mart Üniversitesi, Sosyal Bilimler Enstitüsü, Çanakkale.

GÜNAL, Yılmaz. "Disiplin Cezaları", Ankara Üniversitesi SBF Dergisi, Cilt: 13, Say1: 2, 1958, ss. 190-211.

GÜNEY, Selami ve Orhan ÇINAR. "Serbest Muhasebeci Mali Müşavirlerin (SMMM) Etik Algıları: Erzurum Örneği”, Atatürk Üniversitesi İktisadi ve İdari Bilimler Dergisi, Cilt: 26, Say1: 2, 2012, 91-106.

MAURICE, Jack. Accounting Ethics, 1996, Pitman, London.

MEYMANDİ, A. Roosta; Hossein RAJABDOORY ve Ziba ASOODEH. "The Reasons of Considering Ethics in Accounting Job", International Journal of Management Accounting and Economics, 2 (2), 2015, ss. 136-143.

ÖĞREDIK, Güray. "Muhasebenin Ülkemizdeki Yeri, Önemi, Sorumluluğu ve Geleceği İle Ülkemizdeki Vergi ve Muhasebe Kültürünün Ekonomiye ve Ülkemizin Geleceğine Etkisi”, 2006, http://forum.mustafagulsen.com/showthread.php?5635MUHASEBEN\%DDN\%DCLKEM\%DDZDEK\%DD-YER\%DD-\%D6NEM\%DD (14.04.2016).

ÖNDER, Kazım. Disiplin Mevzuatı Ders Notu, Seri No: 2, Yayın No: 1985/1, 1985, Emniyet Genel Müdürlüğü Yayınları: Ankara.

PUNCH, Keith F. Sosyal Araştırmalara Giriş Nicel ve Nitel Yaklaşımlar, 2005, Siyasal Kitabevi: Ankara

SAKARYA, Şakir; Suat KARA. "Türkiye'de Muhasebe Meslek Etiğine Yönelik Düzenlemeler ve Meslek Mensupları Tarafindan Algılanması Üzerine Bir Alan Araştırması", KMÜ Sosyal ve Ekonomik Araştırmalar Dergisi, 12 (18), 2010, ss. 5772.

SEVİĞ, Veysi. "Muhasebe Bilimi ve Muhasebeci”. Mali Çözüm Dergisi, Say1: 58, 2002, ss. $1-5$.

SORGUÇ, Bahir. Disiplin ve İdari Soruşturma, 1980, Milli Eğitim Basımevi, Ankara

T.C. YASALAR. 3568 Sayıl Serbest Muhasebeci Mali Müssavirlik ve Yeminli Mali Müşavirlik Kanunu, Ankara: Resmi Gazete No: 20194, Resmi Gazete, 13.06.1989.

TÜRMOB, Disiplin Kurulu Kararları, http://www.turmob.org.tr/TurmobWeb/MBS/DisiplinKuruluKararlari.aspx?Pager=1 (10.04.2016).

TÜRMOB, Disiplin Kurulu Kararları, http://www.turmob.org.tr/TurmobWeb/MBS/DisiplinKuruluKararlari.aspx ?Pager=2 (10.04.2016). 
TÜRMOB, Disiplin Kurulu Kararlar1, http://www.turmob.org.tr/TurmobWeb/MBS/DisiplinKuruluKararlari.aspx?Pager=3 (10.04.2016).

TÜRMOB, Disiplin Kurulu Kararları, http://www.turmob.org.tr/TurmobWeb/MBS/DisiplinKuruluKararlari.aspx?Pager=4 (10.04.2016).

TÜRMOB, Disiplin Kurulu Kararlar1, http://www.turmob.org.tr/TurmobWeb/MBS/DisiplinKuruluKararlari.aspx?Pager=5 (10.04.2016).

TÜRMOB, Disiplin Kurulu Kararları, http://www.turmob.org.tr/TurmobWeb/MBS/DisiplinKuruluKararlari.aspx ?Pager=6 (10.04.2016).

TÜRMOB, Disiplin Kurulu Kararlar1, http://www.turmob.org.tr/TurmobWeb/MBS/DisiplinKuruluKararlari.aspx?Pager=7 (10.04.2016).

TÜRMOB, Disiplin Kurulu Kararlar1, http://www.turmob.org.tr/TurmobWeb/MBS/DisiplinKuruluKararlari.aspx?Pager=8 (10.04.2016).

TÜRMOB, Disiplin Kurulu Kararlar1, http://www.turmob.org.tr/TurmobWeb/MBS/DisiplinKuruluKararlari.aspx?Pager=9 (10.04.2016).

TÜRMOB, Disiplin Kurulu Kararlar1, http://www.turmob.org.tr/TurmobWeb/MBS/DisiplinKuruluKararlari.aspx?Pager=10 (10.04.2016).

TÜRMOB, Disiplin Kurulu Kararlar1, http://www.turmob.org.tr/TurmobWeb/MBS/DisiplinKuruluKararlari.aspx?Pager=11 (10.04.2016).

TÜRMOB, Disiplin Kurulu Kararları, http://www.turmob.org.tr/TurmobWeb/MBS/DisiplinKuruluKararlari.aspx?Pager=12 (10.04.2016).

TÜRMOB, Disiplin Kurulu Kararları, http://www.turmob.org.tr/TurmobWeb/MBS/DisiplinKuruluKararlari.aspx?Pager=13 (10.04.2016).

TÜRMOB, Disiplin Kurulu Kararları, http://www.turmob.org.tr/TurmobWeb/MBS/DisiplinKuruluKararlari.aspx?Pager=14 (10.04.2016).

TÜRMOB, Disiplin Kurulu Kararları, http://www.turmob.org.tr/TurmobWeb/MBS/DisiplinKuruluKararlari.aspx?Pager=15 (10.04.2016).

TÜRMOB, Disiplin Kurulu Kararlar1, http://www.turmob.org.tr/TurmobWeb/MBS/DisiplinKuruluKararlari.aspx?Pager=16 (10.04.2016).

TÜRMOB, Disiplin Kurulu Kararları, http://www.turmob.org.tr/TurmobWeb/MBS/DisiplinKuruluKararlari.aspx?Pager=17 (10.04.2016).

TÜRMOB, Disiplin Kurulu Kararlar1, http://www.turmob.org.tr/TurmobWeb/MBS/DisiplinKuruluKararlari.aspx?Pager=18 (10.04.2016). 
TÜRMOB, Disiplin Kurulu Kararları, http://www.turmob.org.tr/TurmobWeb/MBS/DisiplinKuruluKararlari.aspx?Pager=19 (10.04.2016).

TÜRMOB, Disiplin Kurulu Kararları, http://www.turmob.org.tr/TurmobWeb/MBS/DisiplinKuruluKararlari.aspx?Pager=20 (10.04.2016).

TÜRMOB, Disiplin Kurulu Kararlar1, http://www.turmob.org.tr/TurmobWeb/MBS/DisiplinKuruluKararlari.aspx?Pager=21 (10.04.2016).

TÜRMOB, 2015 Faaliyet Raporu, http://www.turmob.org.tr/TurmobWeb/Kurumsal/Raporlar/Faaliyet.aspx (10.04.2016).

TÜRMOB, Serbest Muhasebeci Mali Müşavirler ve Yeminli Mali Müşavirlerin Mesleki Faaliyetlerinde Uyacakları Etik Illkeler Hakkında Yönetmelik, Resmi Gazete Sayı No: 26675, Değişik Başlık: RG-25.12.2012-28508, Resmi Gazete, 19.10.2007.

URAL, Ayhan ve İbrahim KILIÇ. Bilimse Araştırma Süreci ve SPSS ile Veri Analizi, 2013, 4. Bask1, Detay Yayıncılık, Ankara.

UZ, Abdullah. Disiplin Cezalarının Üst Kademe Yöneticiliklere Etkisi, 2013, Adalet Yayınevi, Ankara.

YARDIMCIOĞLU, Mahmut ve Şebnem ADA. "Kronolojik Bir Sirayla Muhasebe ve Finansal Raporlamada Usulsüzlük ve Skandallar", Kahramanmaraş Sütçü Imam Üniversitesi İktisadi ve İdari Bilimler Fakültesi Dergisi; Cilt: 3 Sayı: 1; 2013, ss. 4355.

YILDIZ, Gülsevil. "Muhasebe Mesleğinde Meslek Etiği ve Kayseri İl Merkezinde Bir Uygulama", Erciyes Üniversitesi İktisadi ve İdari Bilimler Fakültesi Dergisi, Sayı: 36, 2010, ss. 155-178. 